\title{
Work Productivity in the Croatian Hotel Industry - Fundamentals and Concepts for Achieving Growth and Competitiveness
}

Ivanaka Avelini Holjevac *

Abstract:

Productivity and product and service quality are the foundations upon which an economy builds its competitiveness, effectiveness and efficiency. Research focuses on the specific characteristics of productivity and the quality of hotel products and services in the case of the Croatian hotel industry. The objective of research is to identify and propose measures to increase productivity and improve the quality of the Croatian hotel industry, and in this way, enhance its competitiveness on the world tourism market.

The task of this research is to provide a theoretical definition of the relationship between productivity, quality and competitiveness; analyses and assess long-term trends in productivity in Croatia's entire hotel industry; assess the quality of hotel offerings; analyze and assess productivity in the case of a large Croatian company; and finally, put forward measures to increase the productivity and competitiveness of the Croatian hotel industry.

Keywords: productivity, competitiveness, quality, hotel industry

JEL: D24

DOI: $10.2478 / v 10033-010-0008-1$

\section{Introduction}

Work productivity and quality of product and service are the basis on which competitiveness is built in today's highly demanding and dynamic tourism market. Anyone wishing to enter, survive and develop on this market must provide a well-designed tourism product adapted to the growing needs, demands and expectations of modern tourists. Whoever is capable of anticipating tourist needs and demands and exceeding tourist expectations will be enjoy the greatest success. Increasing the competitiveness of the hotel industry will lead to faster growth of the Gross Domestic Product (GDP).

Work productivity and quality are the focus of ongoing economic research, the results of which should serve to raise the level of productivity and product and service quality, which in turn will help increase business excellence and the effectiveness and efficiency of the performance of Croatian hotels. Through research, influential factors are identified together with modern personnel management techniques and methods that make it possible to enhance work efficiency and product and service quality. Briefly put: through knowledge to excellence.

This paper applies a theoretical and empirical approach to studying work productivity and the quality management of hotel products and services. The objective of this research is to put forward measures and a model for optimizing productivity and the quality of work, and, in this way, boost the competitiveness of the Croatian tourism product on the European and world tourism markets. This objective underlines the need and importance of research.

Research methods: deduction and induction, comparison and decomposition, analysis and synthesis, various statistical methods.

*Ivanka Avelini Holjevac

University of Rijeka, Faculty of Tourism and

Hospitality Management in Opatija;

e-mail: ivakaah@fthm.hr 


\section{People and Quality}

Education is the difference between poverty and wealth.

Important brands like to stress the amount of handwork that goes into creating a product, as this is what makes the product perfect. For example, "Chanel" ("A woman, a name, a legend"), with its unique, elegant, universally distinctive products, focuses especially on handwork in its marketing - "More than 100 operations, many of them manual, are necessary to bring about in the end a perfect leather product. Elegance means being beautiful both on the inside and out." Another example is "Van Laack" (the leading manufacturer of top-quality men's shirts), a synonym for style and individuality, which grounds it quality on the following message: "If our continued reliance on hand-crafting defies the dictates of prevailing economic logic, this is because only handfinished garments can offer that consummate blend of quality, class and style."

Therefore, human labour is what is most valued and crucial to product and service quality, in comparison with machine labour. "Hand-made" reflects human creativity and is irreplaceable. People like to brandish their potential and this is a vital factor of work motivation (selfactualization). Developing and rewarding quality is possible only if managers adopt the paradigm that only by developing the potential of all workers involved can total product and service quality be achieved.

Quality is the level at which customer needs, wants and expectations are met, but it can also be applied to the workforce, that is, to employees. Job needs can be grouped into two sets of factors (Clark 1999, p.20-21.):

- Hygiene Factors

- Motivational Factors

- Aesthetic needs

- Self-actualization needs

Meeting all the needs of people at work, employees in the workplace, is extremely complex, because of the influence exerted by the many various factors listed above.

According to a Gallup survey, employees consider the following factors as being crucial to job satisfaction (Clark 1999, p.22.):

- Having the opportunity to doing what they know best, every day

- Having a supervisor or other manager who treats them as human beings at work

- Having their opinion taken into consideration
- Having the opportunity to develop and learn

- Working for an employer whose mission it is to make their jobs important

- Having the material and equipment needed to ensure they can do their jobs properly

- Working for a company that cultivates relations with its employees families (family friendly)

Encouraging the motivation of people at work is the task of personnel management and it is carried out through the function of management (leading) and the function of human potential management (staffing).

In leading, a distinction is made between two opposing theories: Theory $\mathrm{X}$, which is based on the assumption that people do not like to work, and Theory $Y$, which is based on assuming all of the best attributes of people, that is, that people like to work, seek pleasure, responsibility and creativity in their work (McGregor 1960). According to Theory $X$, it is possible to increase work efficiency, that is, productivity, through stringent rules, standards, threats and punishments. According to Theory $\mathrm{Y}$, work efficiency is achieved through the delegation of responsibilities and by encouraging creativity, developing intellectual potential, and giving recognition and rewards.

The outcome of Theory $X$ destroys worker motivation and causes productivity to drop, whereas Theory $Y$ fosters work motivation and work productivity.

Work quality and productivity cannot be achieved by intimidating workers with stringent rules. Quality can be ensured only if workers are stimulated to becoming better at doing all the good and worthwhile things that they would otherwise do.

TQM completely changes the way work is organized, the employee-manager relationship and the attitude towards the customer/consumer. In his quality implementation program, Deming provided managers with a 14-point recipe for success (Deming 2000, p. 2324.):

1. Create constancy of purpose toward the improvement of products and services, with the aim to become competitive, stay in business, and provide jobs.

2. Adopt a new philosophy. We are in a new economic age. Management must awaken to the challenge, learn their responsibilities and take on leadership for change.

3. Cease dependence on inspection to achieve quality. Eliminate the need for inspection on a mass basis by building quality into the product (prevention). 
4. End the practice of purchasing on the basis of prices. Instead, minimize total cost. Move towards a single supplier for any one item, based on a long-term relationship of loyalty and trust (partnership).

5. Constantly improve the system of production and service, to improve quality and productivity, and thus constantly decrease costs.

6. Introduce training for every job (everyone must train and learn).

7. Introduce supervision - quality management. The aim of managing (supervising) quality should be to help people, machines and equipment to do a better job. Supervision of management should be improved, as well as supervision of production workers.

8. Drive out fear, so that everyone may work effectively for the company.

9. Remove barriers between departments. People in research, design, sales and production must work as a team, to foresee problems of production and in use that may occur with the product or service (teamwork).

10. Eliminate slogans, exhortations and targets asking for zero defects and new levels of productivity. Such slogans only create an adversarial relationship, as most causes of low quality and low productivity belong to the system itself and are beyond the power of the employees (operators).

11. a) Eliminate work standards (quotas) in production. Substitute leadership.

b) Eliminate management by objectives. Eliminate management by numbers and numerical results. Substitute leadership.

12. a) Remove barriers that deprive employees (hourlypaid workers) the right to take pride in their workmanship. The responsibility of the supervisor must be quality, and not merely numerical results.

b) Remove barriers that deprive people (employees) in management and engineering the right to take pride in their workmanship. This means, inter alia, abolishing annual performance evaluations, as well as management by objectives (The job must be a source of satisfaction, not a place of coercion).

13. Put in place an intensive program of education and self-improvement.

14. Put everybody in the company to work on accomplishing this transformation. The transformation is everybody's job.
This TQM implementation program places quality and measures for continuously improving quality in the forefront, while focusing on ensuring employee satisfaction and teamwork, making everyone responsible for quality and providing continuous education and training. Notably, all these points underline quality in the function of customer, employee and owner satisfaction that can be achieved by increasing work productivity and competitiveness.

In conclusion: people/customers are the ones who define what quality is, while people/workers are the ones who deliver this quality.

What everyone wants is quality of work and quality of life.

\section{Quality Management}

According to the European Charter on Quality:

- Quality is a goal, because the organization must precisely meet the needs and expectations of customers and users, if it wishes to be competitive on the market.

- A methodology that promotes participation, because no one can demand loyalty from people without offering and developing in exchange a suitable working environment - quality also means motivation and responsibility, and the organization, its behaviour and work methodology must be based on initiatives and concern for buyers.

Definitions of quality are (Avelini Holjevac 2002, p.8.):

- quality reflects the ability of a product or service to consecutively satisfy or exceed customer expectations

- quality means getting what you paid for

- quality is not something that is adapted as a special feature, but rather something that is an integral part of the product or service.

Quality, understood to mean "something good", is a very old notion. In economic terms, it is linked to the very beginning of human economic activities, and it has existed from the first primitive societies, throughout our entire history, up to the modern day. Namely, there has always existed some type of specification (in later times, standard) against which an inspector of sorts, in behalf of an owner (chieftain, pharaoh, king, entrepreneur, and others), inspected, approved of or discarded a product or service being offered (Noray 1990, p.3 - 12.). 
Philip B. Crosby, the man who initiated the quality revolution in American business with his book "Quality is Free", claims and proves that:

"Quality is free. It's not a gift, but it is free. What costs money are the unquality things - all the actions that involve not doing jobs right the first time. If you focus on providing quality, you are likely to increase your profit by a value ranging from 5 to 10 percent of the value of your sales. And that is a lot of money - for free" (Crosby 1996, p.9.).

The catchphrases are: quality is free; it is not a gift (you need to think, organize and do better); unquality incurs costs (not doing it right the first time); quality is the easiest way to increase profits (in conditions of fierce competition and market uncertainty).

Customer-orientation presumes the existence of a flexible structure of organizations that are open towards the market and that can easily adjust to change in the marketplace and change in customer/consumer needs. At the same time, the structure of the organisation should be adjustable to changes within the company as well, that is, in alignment with human and materials resources. Only in this way is it possible to achieve optimum performance and be successful on the market (Success through Quality).

The essence of how to organize quality management is best illustrated by Crosby's 14-point quality program: Management commitment and loyalty, Quality improvement teams, Quality measurement (evaluation), Cost of quality, Quality awareness, Corrective measures and activities, Zero Defects planning (establishing a program committee), Manager (supervisor) training, Achieving Zero Defects (Zero Defects Day), Goal setting, Error cause removal, Recognition (Rewarding program), Quality councils, Doing it all over again (Crosby 1996, p.102-111.).

Total Quality Management (TQM) is a system for improving and increasing business flexibility, effectiveness and efficiency. TQM seeks to secure and create conditions in which all employees, through joint efforts and with maximum effectiveness and efficiency, can accomplish one goal: to produce products and render services when, where and how the customer and consumer wants and expects them, and getting it right the first time and every time after that.

Quality is best illustrated by the slogan "We meet your wishes in advance". Hence, customer needs, expectations and wants need to be anticipated, prescribed and met in advance, because quality is defined by the customer (customer-defined quality).

Quality and standards form a unity, because standards represent not only a prescribed quality, but also a measurement of the level of quality achieved.

TQM is fully market-oriented and customer driven. In a total quality system, the customer is king, because it is with the customer that the process begins (what the customer wants) and ends (a satisfied customer).

Securing quality means "getting people to become better at doing all those worthwhile things that they would normally have to do" (Crosby 1996, p.11.).

Today in conditions of fierce competition and increasingly sophisticated customer demands, quality has become the fundamental factor of market survival, profitability and development of a country's overall economy, its individual branches and organizations. Quality is an advantage and necessity of competitiveness in the marketplace.

The association between productivity and quality is best illustrated by the concept and goal of Total Quality Management (TQM), which means doing the right things or doing things effectively, and doing things right or doing them efficiently. This means producing what the customer wants, seeks and expects, while achieving the highest possible level of work productivity. Increased work productivity should not jeopardize product and service quality, as this goes against the principle of effectiveness and efficiency. The customer should not be put at a loss because of reduced quality caused by cutbacks in the number of employees (staff) and savings in labour costs. To avoid this, work standards must be introduced and adhered to. There can be no product and service quality without work standards; the customer is dissatisfied, the work is dissatisfied, and so is the owner. Therefore, a productivity increase resulting in a drop in quality is not profitable.

\section{Measuring Work Productivity and Quality in Croatian Hotels}

\section{Work productivity determines the satisfaction and the quality of the lives of employees.}

The productivity indicator used in the empirical research on work productivity in the Croatian hotel industry and Croatian companies is the number of overnights realized per one employee. This is an indicator that can be easily measured, as the number of overnights 
is continuously monitored in terms of statistics. The number of overnights reflects the real scope of business and, unlike a hotel's revenue (turnover), it is not subject to a change in prices. Although it does not reflect the total quantity of hotel products and services, the number of overnights is a good representative of the physical volume of business.

\begin{tabular}{|c|c|c|c|c|}
\hline Year & $\begin{array}{l}\text { Number of } \\
\text { overnights in } \\
\text { hotels in } \\
\text { '000s }\end{array}$ & $\begin{array}{l}\text { Fixed } \\
\text { base } \\
\text { index }\end{array}$ & $\begin{array}{c}\text { Hotel } \\
\text { employees }\end{array}$ & $\begin{array}{l}\text { Fixed } \\
\text { base } \\
\text { index }\end{array}$ \\
\hline 1974 & 13,373 & 100 & 22,137 & 100 \\
\hline 1975 & 14,350 & 107 & 24,135 & 109 \\
\hline 1976 & 14,280 & 107 & 24,651 & 111 \\
\hline 1977 & 14,989 & 112 & 25,151 & 114 \\
\hline 1978 & 17,436 & 130 & 25,572 & 116 \\
\hline 1979 & 17,948 & 134 & 26,709 & 121 \\
\hline 1980 & 17,521 & 131 & 27,127 & 123 \\
\hline 1981 & 18,194 & 129 & 28,125 & 127 \\
\hline 1982 & 17,773 & 133 & 29,201 & 132 \\
\hline 1983 & 17,764 & 133 & 29,696 & 134 \\
\hline 1984 & 19,486 & 146 & 31,608 & 143 \\
\hline 1985 & 20,975 & 157 & 34,308 & 155 \\
\hline 1986 & 21,219 & 159 & 36,097 & 163 \\
\hline 1987 & 21,986 & 164 & 36,611 & 165 \\
\hline 1988 & 21,768 & 163 & 37,498 & 169 \\
\hline 1989 & 21,552 & 161 & 38,021 & 172 \\
\hline 1990 & 20,716 & 155 & 34,406 & 155 \\
\hline 1991 & 5,904 & 44 & 22,205 & 100 \\
\hline 1992 & 4,983 & 37 & 12,091 & 55 \\
\hline 1993 & 5,729 & 43 & 13,468 & 61 \\
\hline 1994 & 8,433 & 63 & 17,178 & 78 \\
\hline 1995 & 5,587 & 42 & 14,669 & 66 \\
\hline 1996 & 8,551 & 64 & 17,198 & 78 \\
\hline 1997 & 11,247 & 84 & 20,956 & 95 \\
\hline 1998 & 11,388 & 85 & 21,457 & 97 \\
\hline 1999 & 9,605 & 72 & 18,304 & 83 \\
\hline 2000 & 13,164 & 98 & 20,054 & 91 \\
\hline 2001 & 12,735 & 95 & 20,904 & 94 \\
\hline 2002 & 13,130 & 98 & 18,187 & 82 \\
\hline 2003 & 13,217 & 99 & 17,863 & 81 \\
\hline 2004 & 13,745 & 103 & 18,673 & 84 \\
\hline 2005 & 14,964 & 112 & 19,277 & 87 \\
\hline
\end{tabular}

Source: Statistical Yearbooks of the Republic of Croatia (processed data) Table 1: Trends in the number of overnights and employees in hotels in Croatia $1974-2005$

The fixed-base index graph for the number of overnights and the number of employees in Croatian hotels in the $1974-2005$ period shows that the number of employees generally increased at a faster rate than the number of overnights (with minor exceptions), resulting in stagnation and a drop in productivity, apart from the last six years in which overnights show an upward trend, whereas employee numbers show a downward trend, leading to increased productivity.

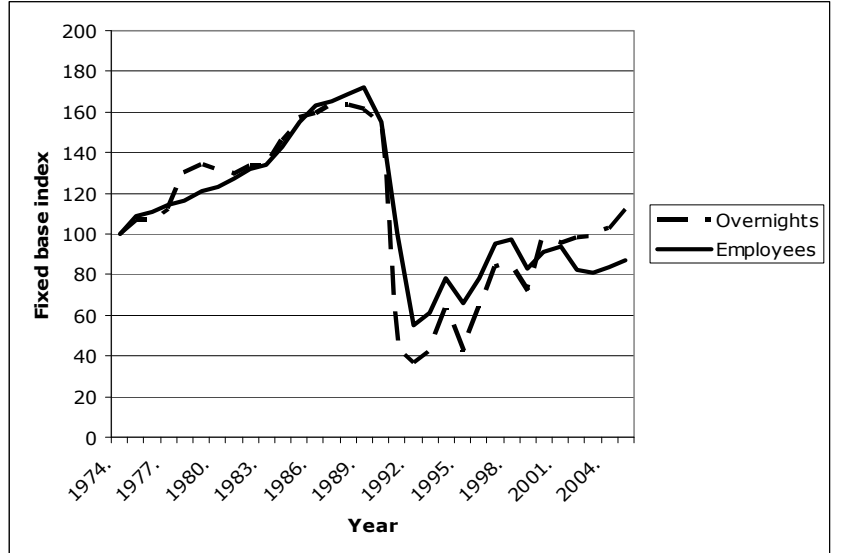

Source: Table 1

Figure 1: Trends in the number of overnights and employees 1997-2004 - fixed-base indexes

Three phases are evident in changes in work productivity over a 31-year period (1974 - 2005): from 1974 to 1990 (16 years) work productivity stagnates and in 1990, plummets (Patriotic War); after 1990, productivity begins to increase more or less, although at a considerably slower rate, up until 1999 (9 years), following which productivity increases (during the last six years) at a substantially faster rate, higher than in 1974, the first year of observation, due to a faster rate of reduction in the number of employees relative to the growth rate of overnights, which remains low as a result of low occupancy rates. For example, overnights in 1974 numbered 13,373,000, whereas 30 years later in 2004, this number was 13,745,000 - a mere 3 percent increase, while the number of employees in 1974 and 2004 amounted to 22,137 and 19,277 (a 16 percent drop), respectively, causing work productivity to rise.

\section{Conclusion}

Work productivity and competitiveness determine a country's economic development and material wealth, but also the satisfaction and the quality of the lives of employees, customers, owners and society in general. For this reason, it is necessary to continuously research, analysis and discover new measures and opportunities for increasing work productivity.

The theoretical and applicative approach to studying work productivity in the Croatian hotel industry has underlined all factors upon which the level of work productivity depends. In particular, research has focused on the impact of personnel management, quality management and performance management on work productivity and the competitiveness of the hotel 


\begin{tabular}{|c|c|c|c|c|c|}
\hline Year & $\begin{array}{c}\text { Number } \\
\text { of } \\
\text { overnight } \\
\text { s in hotels } \\
\text { in '000s }\end{array}$ & $\begin{array}{c}\text { Occupancy } \\
\text { rate } \%\end{array}$ & $\begin{array}{c}\text { Hotel } \\
\text { employees }\end{array}$ & $\begin{array}{c}\text { Average } \\
\text { number of } \\
\text { overnights } \\
\text { per } \\
\text { employee }\end{array}$ & $\begin{array}{c}\text { Fixed } \\
\text { base } \\
\text { index }\end{array}$ \\
\hline 1974 & 13,373 & 37.3 & 22,137 & 604.1 & 100 \\
\hline 1975 & 14,350 & 39.2 & 24,135 & 594.6 & 98 \\
\hline 1976 & 14,280 & 38.2 & 24,651 & 579.3 & 96 \\
\hline 1977 & 14,989 & 38.3 & 25,151 & 596.0 & 99 \\
\hline 1978 & 17,436 & 43.2 & 25,572 & 681.8 & 113 \\
\hline 1979 & 17,948 & 44.0 & 26,709 & 672.0 & 111 \\
\hline 1980 & 17,521 & 42.4 & 27,127 & 645.9 & 107 \\
\hline 1981 & 18,194 & 43.2 & 28,125 & 646.9 & 107 \\
\hline 1982 & 17,773 & 41.1 & 29,201 & 608.6 & 101 \\
\hline 1983 & 17,764 & 40.0 & 29,696 & 598.2 & 99 \\
\hline 1984 & 19,486 & 43.1 & 31,608 & 616.5 & 102 \\
\hline 1985 & 20,975 & 45.0 & 34,308 & 611.4 & 101 \\
\hline 1986 & 21,219 & 43.0 & 36,097 & 587.8 & 97 \\
\hline 1987 & 21,986 & 43.0 & 36,611 & 600.5 & 99 \\
\hline 1988 & 21,768 & 41.7 & 37,498 & 580.5 & 96 \\
\hline 1989 & 21,552 & 41.2 & 38,021 & 566.8 & 94 \\
\hline 1990 & 20,716 & 39.7 & 34,406 & 602.1 & 100 \\
\hline 1991 & 5,904 & 13.1 & 22,205 & 265.9 & 44 \\
\hline 1992 & 4,983 & 10.2 & 12,091 & 412.1 & 68 \\
\hline 1993 & 5,729 & 11.5 & 13,468 & 425.4 & 70 \\
\hline 1994 & 8,433 & 16.9 & 17,178 & 490.9 & 81 \\
\hline 1995 & 5,587 & 11.1 & 14,669 & 380.9 & 63 \\
\hline 1996 & 8,551 & 17.3 & 17,198 & 497.2 & 82 \\
\hline 1997 & 11,247 & 22.8 & 20,956 & 536.7 & 89 \\
\hline 1998 & 11,388 & 22.9 & 21,457 & 530.7 & 88 \\
\hline 1999 & 9,605 & 20.4 & 18,304 & 524.8 & 87 \\
\hline 2000 & 13,164 & 28.5 & 20,054 & 656.4 & 109 \\
\hline 2001 & 12,735 & 33.1 & 20,904 & 609.2 & 101 \\
\hline 2002 & 13,130 & 34.6 & 18,187 & 721.9 & 120 \\
\hline 2003 & 13,217 & 33.2 & 17,863 & 739.9 & 123 \\
\hline 2004 & 13,745 & 33.0 & 18,673 & 736.1 & 122 \\
\hline 2005 & 14,964 & 35.4 & 19,277 & 776.3 & 129 \\
\hline
\end{tabular}

Source: Statistical Yearbooks of the Republic of Croatia (processed data)

Table 2. Productivity standards: Average number of hotel overnights per employee in hotels in Croatia 1974 - 2005

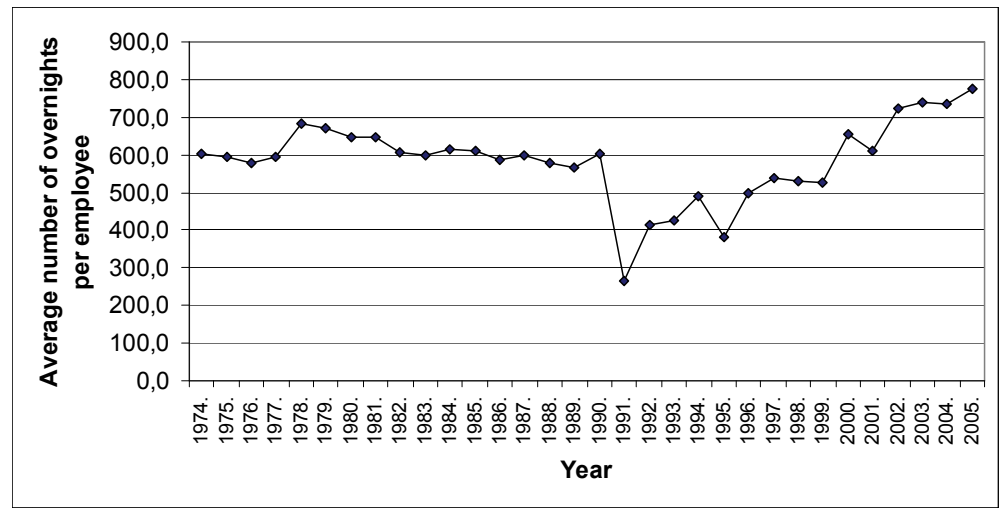

Source: Table 2

Figure 2. Trends in the average number of overnights per employee 1974 - 2005 product and service on the tourism market. Implementing the results of the study may considerably improve work productivity in hotel companies and in the Croatian hotel industry and contribute to the growth and competitiveness of the entire economy of Croatia. ㅁ.

\section{References}

Avelini Holjevac, I. 2002. Quality Management in the Tourism and Hotel industry. Opatija: Faculty of Tourism and Hospitality Management.

Clark, T.J. 1999. Success through Quality - support Guide for the Journey to Continuous Improvement. Milwaukee, Wisconsin: American Society for Quality.

Crosby, B. P. 1996. Quality is free. Zagreb: Privredni vjesnik, Binoza Press.

Deming, W.E..2000. Out of the Crisis. Cambridge, London: MIT Press.

Hope, C.A. 2007. "Is there an inverse relationship between service quality and productivity or not? It's all in the definition!" In Productivity in Tourism Fundamentals and Concepts for Achieving Growth and Competitiveness, edited by P. Keller and T. Bieger, 111122. Berlin: Erich Schmidt Verlag.

Mc Gregor, D. 1960. The Human Side of Enterprise. New York: McGraw-Hill.

Noray, de B. J. 1990. Le mouvement international de la qualité, Traité de la qualité totale. Paris : DUNOD.

Statistical Yearbooks of the Republic of Croatia 19742005. Zagreb: Central Bureau of Statistics. 